\title{
Assessing the Impact of Pronunciation Learning Strategies on Kurdish EFL Learners' Pronunciation Accuracy
}

\author{
Himdad A. Muhammed1, Dlakhshan Y. Othman ${ }^{2}$ \\ ${ }^{1}$ Department of English Language, College of Basic Education, Salahaddin University, Erbil, Kurdistan Region, Iraq \\ ${ }^{2}$ Department of English Language, College of Basic Education, Salahaddin University, Erbil, Kurdistan Region, Iraq
}

\begin{abstract}
The study aimed at investigating the impact of pronunciation learning strategies (in favor of Covert Rehearsal Model) in helping Kurdish EFL learners to acquire accuracy in English pronunciation and detecting the most frequently used strategy types by the learners. A total of 50 Kurdish EFL students of Salahaddin University, English Department took part in the study. The instrument used for collecting data was a validated questionnaire of pronunciation learning strategies. The questionnaire items were adopted from the synthesized taxonomy of pronunciation strategies presented by O'Malley \& Chamots' (1990) and Oxford's (1990) and they were adapted according to Kurdish learners' need. The results indicated that the use of pronunciation learning strategies, especially, Dichersons' self-monitoring strategies were useful for Kurdish learners to improve their pronunciation skills and then consolidate their selfconfidence to bring positive changes in students' pronunciation performance.
\end{abstract}

KEY WORDS: pronunciation learning strategy, Covert Rehearsal, self-esteem development, pronunciation improvement.

\section{INTRODUCTION}

The notions of teaching pronunciation changed significantly over the second half of the twentieth century. Recently, teaching pronunciation received more attention and occupied a relevant place in the language curriculum (Brown, 2001). According to Celce-Murcia, Brinton, \& Goodwin (1996), Pronunciation learning strategies are among the main factors that determine how and how well students learn a second or foreign language pronunciation.

Recognizing the importance of pronunciation strategies has inspirited researchers to look into what strategies to teach and how to teach them in order to facilitate pronunciation learning. In the meantime, the effectiveness of pronunciation learning strategies (PLS hereafter) has been a big concern as well. According to Brown (1992) and Pawlak (2010), the goal of teaching pronunciation to EFL learners is not to make them sound like native speakers of English, but they believed that pronunciation learning strategies give EFL learners an idea of how target language pronunciation works and enable them to perform better in spontaneous speech.

The field of pronunciation learning researches

Koya University Journal of Humanities and Social Sciences (KUJHSS)

Volume 1, Issue 1, 2018

Received 14 April 2018; Accepted 03 August 2018

Regular research paper: Published 12 August 2018

Corresponding author's e-mail: himdad.muhammad@su.edu.krd

Copyright (C2018 Himdad A. Muhammed, Dlakhshan Y. Othman, This is an open access article distributed under the Creative Commons Attribution License. - 0CC BY-NC-ND 4 
attempted to discover which areas of pronunciation are most beneficial for instructors to teach and how to assist EFLs' to improve their pronunciation performance (Celce-Murcia, Brinton, \& Goodwin, 1996). Additionally, new second language researchers tried to discover how second/foreign language learners tackle difficult pronunciation learning tasks through the use of PLS' models.

Thus, the goal behind using PLS and Covert Rehearsal Model (CRM hereafter), in the current study is not only to improve students' ability to hear and articulate English sounds, rhythm, and melody, but also to improve their ability to predict the sounds, rhythm, and melody in words and phrases through the use of orthographically motivated rules and strategies. The motivation of the researchers to conduct the present study is to familiarize Kurdish learners' of English with PLS, especially Dickerson' self-assessment and self-confidence models to enhance pronunciation accuracy and encourage them to participate actively in interactions.

\section{DEFINITIONS}

PLS is among the main factors that help to determine how and how well students learn a second or foreign language pronunciation. Hence, recent researchers have shed light on pronunciation instruction to achieve correct issues that affect the intelligibility of the learners' speech.

The study of PLS has attracted the researcher's attention since the early 1980s.One of the best definitions of language learning strategies provided by Oxford (1990) is "the specific learning strategies as specific actions taken by the learner to make pronunciation learning easier, faster, more enjoyable, more self-directed, more effective, and more transferable to new situations". Yang (1993) describes PLS, as an elementary device that helps the learner control their own cognition. Social strategy, as a type of PLS helps learners develop language skills through communication and interaction with others. Hismanoglu (2006) stated that PLS is a prominent factor in foreign language teaching which granted for nonnative English teachers to improve student's productive skills. Pawlak (2010) identifies PLS as "the techniques or devices which give learners an idea of how target language pronunciation works and enable learners to perform better in spontaneous speech. According to Perterson (2000), PLS can be thought of as the steps taken by second/foreign language learners to enhance their own pronunciation learning. Eckstein (2007) defined pronunciation learning strategies as a field that connects pronunciation learning and instruction with language learning strategies. He considered the PLS as the "vital that help students become aware of what they can do to improve their pronunciation even when their teachers are not available to assist them."

Finally, Celce-Murcia, Brinton \& Goodwin, (2010) regarded pronunciation learning strategy as a critical tool based on theoretical constructs, to identify how pronunciation learning strategies relate to existing pronunciation acquisition theory and to determine how those strategies can be implemented to ease the task of pronunciation learning for individual learners. They believe that English as Foreign Language (EFL) setting, is advocated PLSs that will help them work on their pronunciation outside the classroom in the new communicative approach framework, language is seen as a means of communication. Under the impact of this view, the native-like pronunciation goal has been changed into a more reasonable goal of intelligible and functional communication of the metacognitive strategy.

\subsection{CLASSIFICATION OF PLS}

PLS are identified and categorized by different researchers. Recent studies on PLS identify two taxonomies of pronunciation learning strategies. The first taxonomy, is provided by Peterson (2000) on the basis of her pioneering study. Peterson in her taxonomy is based on Oxford's (1990) pronunciation learning strategies. The second taxonomy of pronunciation learning strategies is proposed by Eckstein (2007). Eckstein taxonomy differed from other classifications of pronunciation learning strategies in that it is based on Kolb's (1984) learning construct.

Oxford (1990) classifies PLs into two groups, Direct and indirect strategies. Direct strategies include: Memory strategies which are used to help learners store information in their memory and connect them with their background knowledge. Cognitive strategies help learners to process, structure, and use the language. The third type of the direct strategies is known as Compensation strategies. This type assists the learners to overcome limitations in speaking and writing.

Indirect strategies include: Metacognitive strategies which are used to help learners to manage the learning process, Affective strategies help learners to arrange, plan and evaluate their learning., Retrieval strategies are used to retrieve language material from storage by using memory searching strategies. Rehearsal strategy is another type of indirect strategies. This strategy is useful for rehearsing target language structures. Covert strategies allow learners to cover their lack of language competence, decrease their anxiety, monitor and obtain self-esteem. Finally, Social strategies are used to help the learners to improve their pronunciation by interacting with each other. 
Depending on Oxford's works, Peterson (2000) conducted a study, which is exclusively devoted to the field of pronunciation learning strategies. The study consists of six strategy groups, 12 strategies and 43 tactics reported through the use of diaries and interviews by eleven research participants. Her work is extremely beneficial as it is the only study up to now that attempts to discover and classify pronunciation learning strategies. Kolb's (1984 as cited in Eckstein, 2007) divides PLSs into four types: Concrete Experience, Reflective Observation, Abstract Conceptualization, and Active Experimentation. Concrete Experience which helps learners to enhance intent listening, representing sounds in memory, focusing on individual syllables, reading aloud, imitating or mimicry of native speakers, and enable them to memorize the pronunciation of words. The second type assists learners to focus on suprasegmentals, distinguishing errors among other speakers, and acquire self-monitoring. The third type enables learners to obtain a general knowledge of phonetics, self-correcting and, monitor themselves to eliminate negative transference. The fourth type enables learners to select clear speech, rehearsing sounds and skipping difficult words during conversation and communication with others.

Eckstein (2007) distinguishes 28 PLSs and connects them to the four stages of pronunciation learning which are formulated by Kolb and add an additional category, named motivation. The first stage is known as concrete experience. In this stage pronunciation learning strategies concentrate on input and practice. The second stage called reflection on observation. In this stage, PLS is connected with noticing and feedback. The third stage named abstract conceptualization. At the third stage learners formulate hypotheses about the pronunciation of the target language. The fourth stage entitled action based on new conceptualization, at this stage, learners tested the hypotheses recognized at the previous stage. The final component of PLS is known as motivational strategies. Motivational strategy is added because Eckstein considers the motivation as a powerful factor in learning the pronunciation of the target language.

Another study on PLS is conducted by Morley in 1991 (as cited in Kroman, 2014), which focus on the identification and description of PLSs. Morley, in his study, develops an instructional framework which works to increase learner autonomy, and encourage learners to be responsible for the development of their own speech. This framework places pronunciation instructors in the role of a "coach" offering learners perception and production strategies, feedback, and error correction. In 1994, Dickerson activated Morley's framework by embedding a crucial component necessary for learners to be able to monitor and correct their own speech.
Lastly, Pawlak's (2010) distinguishes four types of PLS: First, Cognitive strategies, explains how to select particular features of pronunciation and search for opportunities to practice. Second, Metacognitive strategies are important in making use of phonetic symbols and articulatory descriptions, forming and testing hypotheses about pronunciation rules, comparing and contrasting the sounds between L1 and L2. The third type, Affective strategies, helps learners to feel relax when facing pronunciation difficulties and learn them how to reward themselves for making progress. The last type is called Social strategies, which is used to practice pronunciation and correcting learners' errors.

\subsection{DICKERSON'S COVERT REHEARSAL AS A MODEL OF PLS}

Recently, the instructional interventions on PLS followed the procedures of Dickerson's CRM (Sardegna, 2009 , 2011). This model appears to be one of the effective tools for learners to achieve higher proficiency and longterm improvement in pronunciation. Brown (2001) clarified that the instructional goals of pronunciation teaching should empower students to prosper and grow to enable language users to increase their communicative competence. This section sheds light on the process of $\mathrm{CRM}$ and the learning strategies related to it.

Dickerson (1994) conducted a study about the concept of covert rehearsal and clarified how it should be embedded into the English classroom, especially in teaching pronunciation to non- native English learners. He also added that this model helps non- native English learner to be able to monitoring and assessing speech production and performance. The term CRM is defined by Dickerson $(1987,1994,2000)$ as an effective tool that empowers students and enable them to continue to practice and improve their pronunciation even after the class has ended. In general, Dickerson's models, selfmonitoring, self-correction, and self-practice enable EFL learners to remember how to recognize and produce the sound in an accurate way. Chang $(2012$, p. 31) stated, "it was found that the persistence of practicing pronunciation with the covert rehearsal strategies that were taught during instruction enabled learners to maintain their improvement in the long run."

Moreover, Dickerson's CRM provided a guiding framework for integrating pronunciation instruction. It argued that the rules intended to empower learners to be well practiced and internalized personally rather than in the classroom. Depending on Dickerson's idea, the basic constituents of the CRM can be used for practicing the three skills, perception, production, and prediction, they 
are outlined in Dickerson $(1984,2000)$ as follows:

1. Obtain privacy in learning

2. Achieve aloud performance

3. Monitor and assess performance

4. Help learners to compare their performance with models

5. Revise their performance to match the models

6. The practice changed performance aloud until fluent Brown (1992) believed that one of the basic elements of successful learning is the principle of autonomy. Based on this concern, Dickerson tried aid learners to set their goals both within the structure of a classroom curriculum and to pursue them to monitor their learning process independently. They (1998) believed that direct involvement of non- native English learners in their own learning will encourage them to have self- autonomy and increase their motivation to learn. Brown \& Hudson also asserted that self-involvement offers certain benefits through self-monitoring and self-assessment.

Sardegna \& McGregor (2012), thought that during implementing CRM into the curriculum, it is important for pronunciation teachers to set prominent goals for teaching pronunciation through designing training courses depending on the students' levels and establishing intuitive rules that fit the learners' background knowledge and understanding level. Depending on the above points, pronunciation teachers must attempt to choose appropriate instructional teaching methods to seize their teaching target.

According to Sardegna (2009, 2011, 2012), using the CMR in teaching segmental, and suprasegmental feature to EFL learners will assist non- native English them to improve their pronunciation performance progressively. Sardegna (2009) analyzed the effectiveness of the pronunciation strategies in enhancing learners' production improvements and identified the general goals of PLS which can be used by pronunciation teachers to foster learner autonomy and encourage self monitoring. Sardegna in her study succeeded in helping learners improve in reading primary phrase stress, construction stress, and word stress during the course and even after the course ended. She helped the learners to retain much of their pronunciation improvement.

In sum, CRM is considered as a diagnostic assessment to analyze the learners' speech production, especially in a non -native learners' classroom, and it helps non-native pronunciation teachers to classify and select suitable instructional strategies to solve most of the problems that their students face during learning English pronunciation in recorded time.

\section{PREVIOUS RESEARCH INTO PRONUNCIATION LEARNING STRATEGIES}

Pronunciation strategy, as mentioned previously, is a prominent factor in the pronunciation learning process. And since sounds play an important role in communication, foreign language teachers must attribute proper importance to teaching pronunciation in their classes. In the years between 2000-2016, many researchers have focused on learning strategies in relation to the pronunciation of a second/foreign language. The review of the literature, in this section, will discuss the role of pronunciation strategies in helping foreign Learners to enhance and increase self- monitoring and selfconfidence in learning English pronunciation.

One of the studies that focused exclusively on pronunciation learning strategies was conducted by Peterson (2000). Peterson in a study entitled "Pronunciation Learning Strategies: A First Look" studied some learning strategies used by Spanish adult learners, as foreign language learners, to improve their pronunciation and to repair their communication breakdown. In the above- mentioned study, he investigated pronunciation learning strategies used by native English speakers learning Spanish as L2. The participants were eleven students who were at three different levels (i.e., beginners, intermediate and advanced) from The Ohio State University's Spanish classes. The researcher in this study examined twelve strategies through the use of diaries and interviews by these eleven adult learners. The result of the study revealed that language learning strategies and pronunciation are not only in need of empirical research, but they are also necessary for successful language learning.

Derwing and Rossiter (2002) carried out a study on 201 multilingual learners of English to determine the nature and extent of pronunciation instruction in English classrooms in Canada. They attempted to investigate which pronunciation strategies should be used by English pronunciation teachers to resolve adult ESL learners' defects in pronunciation and to overcome the communication breakdown caused by pronunciation difficulties. The researchers chose Breitkreutz $s^{\prime}$ pronunciation strategy as a model in their study with some changes and additions by adding a new set of pronunciation strategies. Students, in this study, have ranged from low-intermediate to high-intermediate of their ESL proficiency. Concerning the results of this study, pronunciation changed when being excited or nervous. Furthermore, the findings unearthed that students perceiving a pronunciation problem in their communication were not getting a suitable instruction or 
the instruction they received was ineffective (Breitkreutz, Derwing, \& Rossiter, 2001).

Vitanova and Miller (2002) carried out a pilot- study to find out the correlation between motivation and pronunciation training. The study used 100 participants from an adult, college-level. The participants were ESL graduate students who had learned various pronunciation strategies on their own without the aid of a teacher. The factual number of participants was not given in the study. The researchers, in this study, examined the strategies and components of pronunciation instruction the learners found most valuable. The researchers assumed that learners would continue improving outside the classroom if they were provided with pronunciation strategies. By using openended prompts to elicit ESL graduate students' reflections on learning pronunciation, the researchers found that students had positive comments on the empowerment of self-monitoring, self-correction, and autonomous learning strategies. That is, students recognized the value of metacognitive strategy training.

Osburne (2003) conducted a study under the title "Pronunciation strategies of advanced ESOL learners". The researcher looked through to find out the impact of using pronunciation learning strategies for advanced second language learners. He investigated the employment of pronunciation learning strategies by 50 advanced learners of English. The participants were from sixteen different native language groups. The participants were asked to report what they did to improve their pronunciation. The participants were first asked to record a language learning autobiography. Then, while the experimenter and the participants listened to the recording together, participants were asked to use better pronunciation to repeat certain sentences in their autobiographies recordings. As a result, the researcher categorized eight main strategies for pronunciation improvement.

A study conducted by Eckstein (2007) focused on the relationship between pronunciation learning strategies used by 183 adult ESL Brigham Young University learners and their spontaneous pronunciation performance. The researcher, in this study, aimed to determine the correlation between pronunciation learning strategies used by adult ESL learners and their spontaneous pronunciation skill. He also examined the strategic learning of pronunciation through the use of pronunciation learning strategies that are linked to pronunciation acquisition theory. He employed strategic pronunciation learning questionnaires and a standardized speaking level achievement test for data collection. The results of this study revealed that immediate self-correction and asking for help were the most frequently used strategies for pronunciation improvement while using symbol systems and one's native sound system was the least preferred.

A qualitative study conducted by Chang (2012) at the University of Texas to review the literature on language learning strategies and strategy training, with a specific focus on pronunciation. The study seeks to explore the literature surrounding pronunciation learning strategies and strategy training in order to suggest a pedagogical lesson that facilitates students' self-instruction on pronunciation. Chang studied Oxford's (1990) Taxonomy of Language Learning Strategies; Peterson's (2000) Categorization of Pronunciation Learning; and Connection between Kolb's (1984) Construct, SLA, and Pronunciation Learning Strategies Proposed by Eckstein (2007). He, in his study, analyzed the history of pronunciation teaching and learning and explained that many pronunciation experts highlighted that although the pronunciation strategy field is still in its early stages of development, but these strategies had redefined the roles of teachers and learners in the field of pronunciation instruction. He also focused on the importance of the role of teachers as facilitators, on activating students to be independent and autonomous pronunciation learners. The results of the study showed that students generally hold a positive attitude toward using pronunciation strategy and pronunciation class can be organized through by using different pronunciation strategies.

Finally, Akyol (2012) presented a quasi-experimental study under the title "Goals and Priorities for English Pronunciation Instruction A study on identifying pronunciation learning strategies of Turkish EFL learners". The participants were eighty-two Turkish university students learning English. The main objectives were to examine the types of learning strategies used by novice EFL teachers at the English Language Teaching Department to improve English pronunciation. The researcher used the Pronunciation Strategies questionnaire based on taxonomies of pronunciation learning strategies presented by Oxford (1990) and Peterson (2000) for collecting the data. The outcomes of this study indicated that the uses of pronunciation learning Strategies are necessary to make pronunciation learning much more entertaining, autonomous and more suitable to meet the demands of communicative-oriented classes.

Although few, but prominent studies were conducted to date on pronunciation learning strategies, none of the above mentioned studies were exclusively conducted to reveal the effect of CRM on learners' pronunciation outcome. The researchers, in the current study, try to cover the shortcoming in the pronunciation classes through the use of the pronunciation learning Strategy (in 
favour of CRM). More precisely, they focus on the effectiveness of Dickersons' self- confidence and selfmonitoring model to help the Kurdish EFL students to enhance their own pronunciation learning. They also tried to investigate to what extent does integrating selfconfidence and self-monitoring strategies, in particular: self-assessing, monitor-performance critical listening, transcription, annotation, and rehearsing, affect first-year Kurdish students' pronunciation accuracy. The successful application of this model will open a practical way for the students to learn pronunciation more effectively and assist the teachers to be more comfortable in selecting appropriate pronunciation techniques to apply in the classroom.

\section{METHOD}

\subsection{PARTICIPANTS}

Fifteen randomly selected freshman students took part in this study. The participants were Kurdish students learning English as a foreign language at Salahaddin University, College of Basic Education. They were introduced to different types of PLS, including the principles of CRM, in the pronunciation class by their pronunciation instructor, and they were instructed to employ these strategies, especially Dickersobs' selfmonitoring and self-confidence to enhance their own pronunciation learning.

\subsection{THE AIM}

This paper aims at examining the effect of pronunciation Learning Strategy (in favour of Covert Rehearsal's selfesteem and self- monitoring) to improve English pronunciation of Kurdish learners by developing their self-esteem and self-monitoring.

\subsection{STUDY QUESTION}

The researchers intend to seek answers to the following questions:

1. To what extent does covert rehearsal strategy (as the most common pronunciation learning strategy) develop students' pronunciation accuracy?

2. Which pronunciation learning strategies, are used more frequently by Kurdish EFL students?

\subsection{INSTRUMENTS}

In order to answer the questions raised above, a questionnaire, a 34 -item questionnaire of Pronunciation learning strategies were developed by the researchers based on the O'Malley \& Pierce (1991) and Oxford's (1990) classification. The questionnaire consisted of two parts: the first part included 17 items which measured participants to what extent Kurdish learners use self esteem strategies to improve their pronunciation accuracy while the second part included 17 items to measure to what extent Kurdish learners use selfmonitoring strategies to enhance accuracy in English pronunciation.

These 34 learning strategies were selected out of 50 in the validation process. In order to check the reliability of the questionnaire. Then the items on the questionnaire were piloted by applying Cronbach's alpha measurement which to calculate the index, which was equal to $(0.70)$. And the learners were asked to report on a scale of 1 to 5 how they use each strategy. The choices were 'always' (5 points), 'usually' (4points), 'sometimes' (3 points), 'rarely'(2 points) and 'never' (1 point).

\subsection{PROCEDURE}

To achieve the aims of the study the following procedure is taken:

- Presenting theoretical background on pronunciation learning strategies.

- Conducting a literature review.

- Constructing a questionnaire to the participants.

- Collecting data from the selected samples of the study through the study tool.

- Analyzing the data

\subsection{RESULTS AND FINDINGS}

The results of the students' attitudes on Covert Rehearsal (as a model PLS) show that there is a positive relationship between pronunciation learning strategy use and Kurdish learners' pronunciation improvement. All the participants observed some degree of progress in their English pronunciation and felt strongly that they are using of PLS played a role in the improvement.

The questionnaire which aims at surveying Kurdish learners' attitude toward the using of PLS that focused on the role of self-confidence and self -monitoring for improving their English pronunciation is represented in table (1\&2).

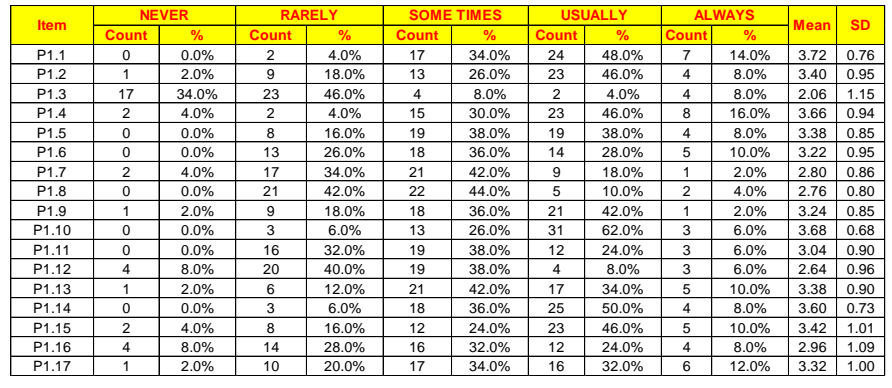


Table (1) Kurdish learners Response percentage of the options on each item of the pronunciation learning strategies questionnaire

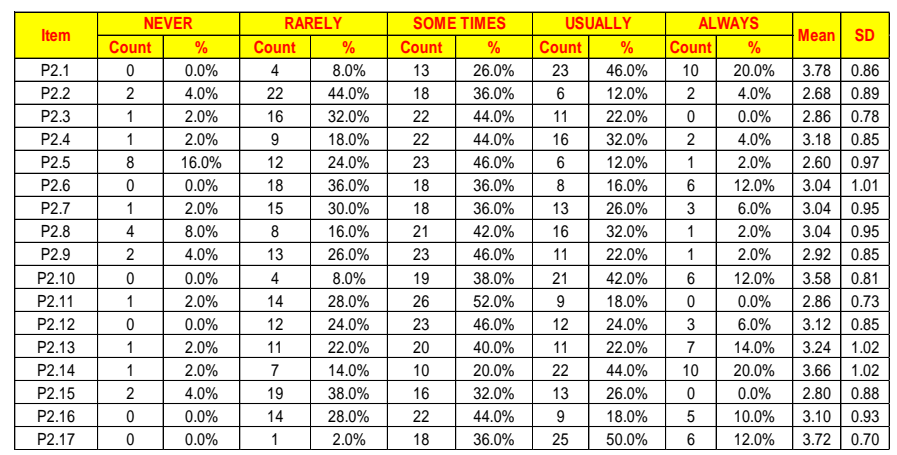

Table (2) Kurdish learners' response percentage of the options on each item of the pronunciation learning strategies questionnaire

The most often used strategy has been used by Kurdish was: increasing personal practice to get native-like pronunciation $(\mathrm{M}=3.78)$. The students reported that they always used this rote learning strategy. The students also reported that continually use an English- English dictionary to memorize the pronunciation of a new word $(\mathrm{M}=3.76)$. Another constantly used strategy by Kurdish learners in their pronunciation development was: repeating the difficult words over and over silently until they memorized them $(\mathrm{M}=3.72)$. The Kurdish learners' goal of learning English pronunciation was improving their speaking skill and not to pass the exam $(M=3.66)$. The results revealed that most of the Kurdish learners of English, continuously listened recording data (by a native speaker), such as, songs, audio books, etc. to have nativelike pronunciation (M=3.66) see table (3).

The less commonly used strategy by Kurdish EFL learners was repeating a word aloud several times. The students added that they never used this strategy at all. $(M=2.06)$. They also reported that they never use selfrewarding, as a self -esteem strategy for pronunciation improvement $(\mathrm{M}=2.60)$. Another strategy which rarely used by Kurdish learners in English pronunciation learning was using a mirror to watch how they articulate their organs when they produce a given sound and compare it with the articulation of the model in the books $(M=2.64)$. The results of the students' attitudes on PLS also showed that they hardly used a notebook to register the new word, that they had learned with their transcriptions $(\mathrm{M}=2.64)$. Kurdish learners believed that they could not learn pronunciation materials when they find the topics dull and uninteresting. They by encouraging themselves worked to improve their pronunciation even if others think that their pronunciation was not good enough $(\mathrm{M}=2.68)$ see table (4).

\begin{tabular}{|l|l|l|l|}
\hline \multicolumn{1}{|c|}{ Items } & Mean & $\%$ & SD \\
\hline $\begin{array}{l}\text { I'm certain that by practice I can get } \\
\text { native-like pronunciation }\end{array}$ & 3.78 & 20.0 & 0.86 \\
\hline $\begin{array}{l}\text { I use an English- English dictionary to } \\
\text { memorize the pronunciation of a new } \\
\text { word. }\end{array}$ & 3.72 & 16.0 & 0.76 \\
\hline $\begin{array}{l}\text { When I find difficult word to } \\
\text { pronounce. I practice repeating the } \\
\text { difficult word over and over to myself } \\
\text { until I memorize it. }\end{array}$ & 3.72 & 14.0 & 0.40 \\
\hline $\begin{array}{l}\text { I want to learn English pronunciation } \\
\text { to improve my speaking skill and not } \\
\text { to pass the exam. }\end{array}$ & 3.66 & 14.0 & 1.02 \\
\hline $\begin{array}{l}\text { I listen to the recording data (song, } \\
\text { audio books, etc.) to have native- like } \\
\text { pronunciation }\end{array}$ & 3.66 & 16.0 & 0.94 \\
\hline
\end{tabular}

Table (3). The five most frequently utilized pronunciation learning strategies by Kurdish learners $(n=50)$

\begin{tabular}{|l|l|l|l|}
\hline Items & Mean & $\%$ & SD \\
\hline $\begin{array}{l}\text { I repeat the new word several times } \\
\text { loudly to memorize its } \\
\text { pronunciation }\end{array}$ & 2.06 & 34.0 & 1.15 \\
\hline $\begin{array}{l}\text { I rewarded myself if I get progress } \\
\text { in pronouncing difficult words or } \\
\text { phrases. }\end{array}$ & 2.60 & 16.0 & 0.97 \\
\hline $\begin{array}{l}\text { I use a mirror to watch how I } \\
\text { articulate my organs when I } \\
\text { produce a given sound and } \\
\text { compare it with the articulation of } \\
\text { the model in the books }\end{array}$ & 8.64 & 8.0 & 0.96 \\
\hline $\begin{array}{l}\text { I use a notebook to register the new } \\
\text { words that I have learned with } \\
\text { their transcriptions. }\end{array}$ & 2.64 & 4.0 & 0.88 \\
\hline $\begin{array}{l}\text { I encourage myself work to } \\
\text { improve my pronunciation even if } \\
\text { others think that my pronunciation } \\
\text { is not good }\end{array}$ & 2.68 & 4.0 & 0.89 \\
\hline
\end{tabular}

Table (4) the five less frequently utilized pronunciation learning strategies by Kurdish learners $(n=50)$

Other strategies used from time to time included memorizing the pronunciation of a given word by associating it with words having the same rhyme and tone $(\mathrm{M}=3.40)$. They asserted that they sometimes compared sound articulation in the mother language with the articulation of the similar sounds in the target language $(\mathrm{M}=3.38)$. The results also revealed that Kurdish learners, in general, did not participate in the class discussions to avoid making mistakes $(M=3.04)$. Some of the learners revealed that they were seeking to find different strategy to learn English pronunciation by themselves $(\mathrm{M}=2.86)$. Every so often, the learners recorded their voices while producing the new words and listen to their record $(M=2.80)$, and using the new word in a context to remember it later was repeatedly used by most of the learners $(M=2.76)$. 
According to the results, the Kurdish EFL learners rarely made notes to guess the pronunciation of a given word before checking it in the dictionary $(\mathrm{M}=3.68)$. It was found in the results, they occasionally used phonetic transcription to master the correct pronunciation of the new learned words $(\mathrm{M}=3.32)$, and Kurdish learners frequently worked on practice exercises in pronunciation books in the leisure time $(\mathrm{M}=3.10)$. They substituted the words that they were not sure of its pronunciation by words with easy pronunciation during speaking $(\mathrm{M}=$ 2.92).

The results also showed, when the Kurdish learners wanted to overcome the lack of knowledge in the area of the pronunciation of the English language, they often try to familiarize themselves with the rules of English pronunciation $(\mathrm{M}=2.86)$ Sometimes they check the words that they use with themselves or friends before speaking $(M=3.58)$. Rarely did they correct their friends' mispronunciation even if they know the correct pronunciation of the mispronounced words $(\mathrm{M}=3.12)$.

\begin{tabular}{|c|c|c|c|c|c|}
\hline & Mean & $\mathbf{N}$ & SD & T-test & P-value \\
\hline $\begin{array}{l}\text { Total. Self- } \\
\text { monitoring items }\end{array}$ & 3.19 & 50 & 0.27 & \multirow{2}{*}{1.51} & \multirow{2}{*}{0.137} \\
\hline $\begin{array}{l}\text { Total. Self- } \\
\text { confidence items }\end{array}$ & 3.13 & 50 & 0.27 & & \\
\hline
\end{tabular}

Table (5) Correlation coefficient between using selfmonitoring strategy and self-esteem strategy

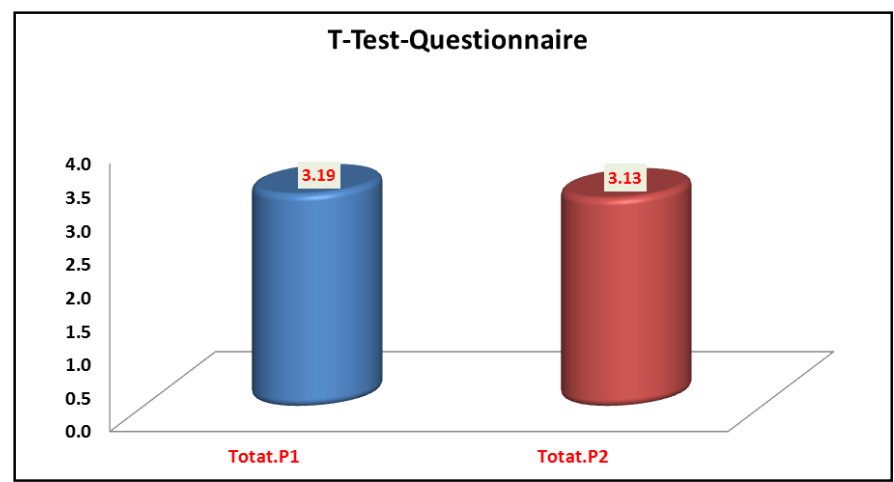

Figure (1) Correlation coefficient between using selfmonitoring strategy and self-esteem strategy

Furthermore, the correlation coefficient between the parts of the CRM questionnaire (Kurdish learners' attitude towards using self-monitoring and self-confidence) demonstrate that the Standard Deviation in the two strategy groups is low $(\mathrm{SD}=0.27)$, which indicates that the students' use of both strategies is similar and the P. value was $(p>$. 0.137) which means that there is no significant correlation between using self- monitoring strategy $(M=3.19)$ and self-esteem strategy $(M=3.13)$ of the PLS; therefore, using both strategies has nearly the same effect on Kurdish learners' pronunciation development (see table $5 \&$ figure 1 ).

\subsection{CONCLUSION}

Through the study, it has been concluded that Kurdish EFL students' attitudes on PLS show that there is a considerable degree of progress in participants' English pronunciation and the use of PLS played a significant role in their pronunciation improvement. The results also demonstrate a positive relationship between PLS and pronunciation learning developments, since the self confidence and self -monitoring strategies are helpful to enhance their own pronunciation learning.

The results of the study, as clearly shown in the above tables, indicate that some strategies (e.g., practicing, using an English - English dictionary, self- repetition, self- correction, listening to recording data by native speakers) were used by participants repeatedly simply because these strategies offer additional pronunciation learning ideas.

Based on the results of the study, it is recommended that for Kurdish students to overcome the lack of knowledge in the area of the English pronunciation, they need to acquaint themselves with the self-confidence and self -monitoring strategies to obtain pronunciation accuracy.

\section{REFERENCES}

Akyol, T. (2012). A study on identifying pronunciation learning strategies of Turkish EFL learners. ProcediaSocial and Behavioral Sciences, 70, 1456-1462.

Brown, H. D. (1992). Approaches to Pronunciation Teaching. Hertfordshire: Phoenix ELT.

Brown, H. D. (2001). Teaching by principles: An interactive approach to language. New York: Longman.

Brown, J. D. \& Hudson, T. (1998). The alternatives in language assessment. TESOL Quarterly, 32 (4): 653675. Available at: http://www.personal.psu.edu/kej1/APLNG_493/ol d_site/brown_hudson.pdf. [Accessed: Jul. 26, 2007].

Breitkreutz, J., Derwing, T. M., \& Rossiter, M. J. (2001). Pronunciation teaching practices in Canada. TESL Canada Journal, 19 (1), 51-61.

Celce-Murcia, M., Brinton, D. M., Goodwin, J. M., (1996). Teaching pronunciation: A reference for teachers of 
English to speakers of other languages. Cambridge University Press.

Celce-Murcia, M., Brinton, D. M., Goodwin, J. M. \& B,A.Griner (2010). Teaching pronunciation: A course book and reference guide. 2nd edition. Cambridge, NY: Cambridge University Press.

Chang, C. H. (2012) Instruction on Pronunciation Learning Strategies: Research Findings and Current Pedagogical Approaches (M.A Thesis, University of Texas) Available at: http://www.ssllt.amu.edu.pl

Derwing, T. M., \& Rossiter, M. J. (2002). ESL learners' perceptions of their pronunciation needs and strategies. System, 30(2), 155-166.

Dickerson, W. B. (1987). Explicit rules and the developing interlanguage phonology. In James \& J. Leather (Eds.), Sound Patterns in Second Language Acquisition (pp.121-140). Dordrecht, Holland: Foris.

Dickerson, W. B. (1990). Morphology via orthography: A visual approach to oral decisions. Applied Linguistics, $11,238-252$.

Dickerson, W. B. (1994). Empowering students with predictive skills. In J. Morley (Ed.), Pronunciation pedagogy and theory: New views, new directions (pp. 17-33).Alexandria, VA: TESOL Publications.

Eckstein, G. T. (2007). A correlation of pronunciation learning strategies with spontaneous English pronunciation of adult ESL learners. MA Thesis, Brigham Young University. UK.

Hişmanoğlu, M. (2012). An Investigation of Pronunciation Learning Strategies of Advanced EFL Learners. H.U. Journal of Education, 43 (2012), 2462587

Kolb, D. (1984). Experiential learning: experience as the source of learning and development. Englewood Cliffs, NJ: Prentice Hall.

Morley, J. (1991). The pronunciation component in teaching English to speakers of other languages, TESOL Quarterly, 25(1), 51-74.

Osburne, A. G. (2003). Pronunciation strategies of advanced ESOL learners. IRAL, 41,131-143.

O'Malley, J. M., \& Chamot, A. U. (1990). Learning strategies in second language acquisition. Cambridge: Cambridge University Press.

O'Malley, J.M., \& Pierce, L.V. (1991). A survey of state assessment practices effecting language minority students. Arlington, VA: Georgetown University Evaluation Assistance Center (FAC) -East.
Oxford, R.L. (1990). Language Learning Strategies: What Every Teacher Should Know. Boston: Heinle \& Heinl Oxford, R.L. (1990). Language Learning Strategies: What Every Teacher Should Know. Boston: Heinle \& Heinl.

Pawlak, M. (2010). Designing and piloting a tool for the measurement of the use of pronunciation learning strategies. Research in Language, 8, 189-202.

Peterson, S.S. (2000). Pronunciation Learning Strategies: A First Look. Retrieved from the Eric database. (ED495903).

Sardegna, V. G. (2009). Improving English stress through pronunciation learning strategies. Doctoral dissertation, University of Illinois at UrbanaChampaign (UMI No. 3363085).

Sardegna, V. G. (2011). Pronunciation learning strategies that improve ESL learners' linking. In. J. Levis \& K. LeVelle (Eds.). Proceedings of the 2nd Pronunciation in Second Language Learning and Teaching Conference, Sept. 2010. (pp. 105-121), Ames, IA: Iowa State University.

Vitanova, G., \& Miller, A. (2002). Reflective practice in pronunciation learning. The Internet TESL Journal, 8 (1). . [0n line] available: http://iteslj.org. [Accessed: April 4, 2012].

Yang, N. D. (1993). Beliefs about language learning and learning strategy use: A study of college students of English in Taiwan. The 10th Conference on English Teaching and Learning in the Republic of China (pp. 193-219). Taipei: The Crane Publishing Co., LTD.

\section{APPENDIX (1)}

\section{Questionnaire for students}

\section{Dear students}

This questionnaire is a tool for investigating the effectiveness of the pronunciation learning strategy on Kurdish learners of English. It is in the form of strategies which is used to identify to what extent these strategies help Kurdish learners to acquire selfmonitoring and self-confidence during learning English pronunciation.

- Please select the appropriate response, according to the following scale:

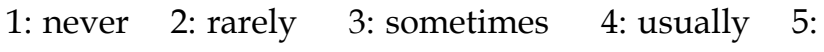
always 
Your answers will be kept anonymous and will be used only for research purposes. Part one: General tips and strategies for obtaining self-monitoring

\section{Part one: Statements concerning with Self-monitoring}

\begin{tabular}{|c|c|c|c|c|c|c|}
\hline No & Self- monitoring items & 1 & 2 & 3 & 4 & 5 \\
\hline 1. & $\begin{array}{l}\text { I use an English- English dictionary } \\
\text { to memorize the pronunciation of a } \\
\text { new word. }\end{array}$ & & & & & \\
\hline 2 & $\begin{array}{l}\text { I memorize the pronunciation of a } \\
\text { given word by associating it with } \\
\text { words having the same rhyme and } \\
\text { tone. }\end{array}$ & & & & & \\
\hline 3 & $\begin{array}{l}\text { I repeat the new word several times } \\
\text { aloud to memorize its pronunciation. }\end{array}$ & & & & & \\
\hline 4 & $\begin{array}{l}\text { I repeat the new word silently to } \\
\text { myself to memorize its } \\
\text { pronunciation. }\end{array}$ & & & & & \\
\hline 5 & $\begin{array}{l}\text { I associate the new word with a word } \\
\text { in my native language ( if there any) } \\
\text { So that I do not forget it. }\end{array}$ & & & & & \\
\hline 6 & $\begin{array}{l}\text { I listen to the recording (by a native } \\
\text { speaker)to have native like } \\
\text { pronunciation. }\end{array}$ & & & & & \\
\hline 7 & $\begin{array}{l}\text { I record my voice while producing } \\
\text { the new words and listen to my } \\
\text { record. }\end{array}$ & & & & & \\
\hline 8 & $\begin{array}{l}\text { I use the new word in a context to } \\
\text { remember it later. }\end{array}$ & & & & & \\
\hline 9 & $\begin{array}{l}\text { I review the pronunciation of } \\
\text { recently learned word regularly. }\end{array}$ & & & & & \\
\hline 10 & $\begin{array}{l}\text { I try to guess the pronunciation of a } \\
\text { given word before checking it in the } \\
\text { dictionary. }\end{array}$ & & & & & \\
\hline 11 & $\begin{array}{l}\text { I try to articulate my organs of speech } \\
\text { like- native speakers during sound } \\
\text { production to have native like } \\
\text { pronunciation. }\end{array}$ & & & & & \\
\hline 12 & $\begin{array}{l}\text { I use a mirror to watch how I } \\
\text { articulate my organs when I produce } \\
\text { a given sound and compare it with } \\
\text { the articulation of the model in the } \\
\text { books. }\end{array}$ & & & & & \\
\hline
\end{tabular}

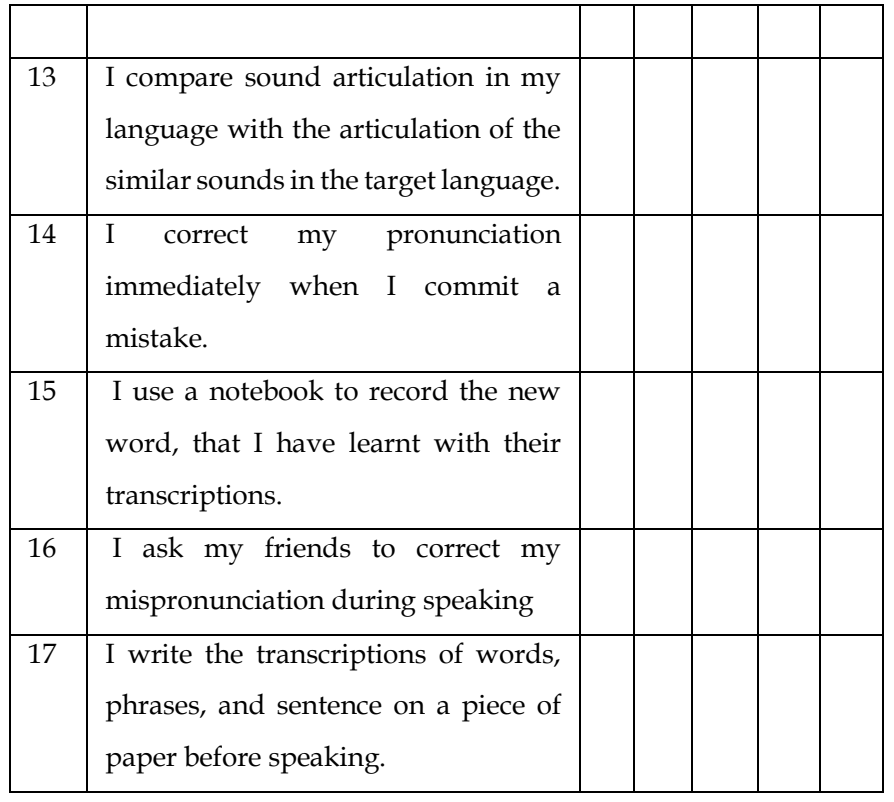

Part two: Statements concern self confidence

\begin{tabular}{|c|c|c|c|c|c|c|}
\hline No & self-confidence items & 1 & 2 & 3 & 4 & 5 \\
\hline 1 & $\begin{array}{l}\text { I'm certain that by practice I can get } \\
\text { native like pronunciation }\end{array}$ & & & & & \\
\hline 2 & $\begin{array}{l}\text { I encourage myself work to improve } \\
\text { my pronunciation even if others } \\
\text { think that my pronunciation is not } \\
\text { good. }\end{array}$ & & & & & \\
\hline 3 & $\begin{array}{l}\text { Before I start correcting any } \\
\text { mistakes that I might be making, I } \\
\text { must first familiarize myself with } \\
\text { the rules of pronunciation. }\end{array}$ & & & & & \\
\hline 4 & $\begin{array}{l}\text { I use the words that have difficult } \\
\text { pronunciation during speaking, } \\
\text { even if I have difficulty with their } \\
\text { pronunciation. }\end{array}$ & & & & & \\
\hline 5 & $\begin{array}{l}\text { I reward myself if I make progress in } \\
\text { pronouncing difficult words or } \\
\text { phrases. }\end{array}$ & & & & & \\
\hline 6 & $\begin{array}{l}\text { I am not afraid of making } \\
\text { pronunciation mistakes because I } \\
\text { learn from my mistakes. }\end{array}$ & & & & & \\
\hline 7 & $\begin{array}{l}\text { I don't feel shy to ask my teachers } \\
\text { and friends about the pronunciation } \\
\text { of word(s) that I don't know }\end{array}$ & & & & & \\
\hline 8 & $\begin{array}{l}\text { I I don't participate in class } \\
\text { discussions to avoid making } \\
\text { mistakes. }\end{array}$ & & & & & \\
\hline
\end{tabular}




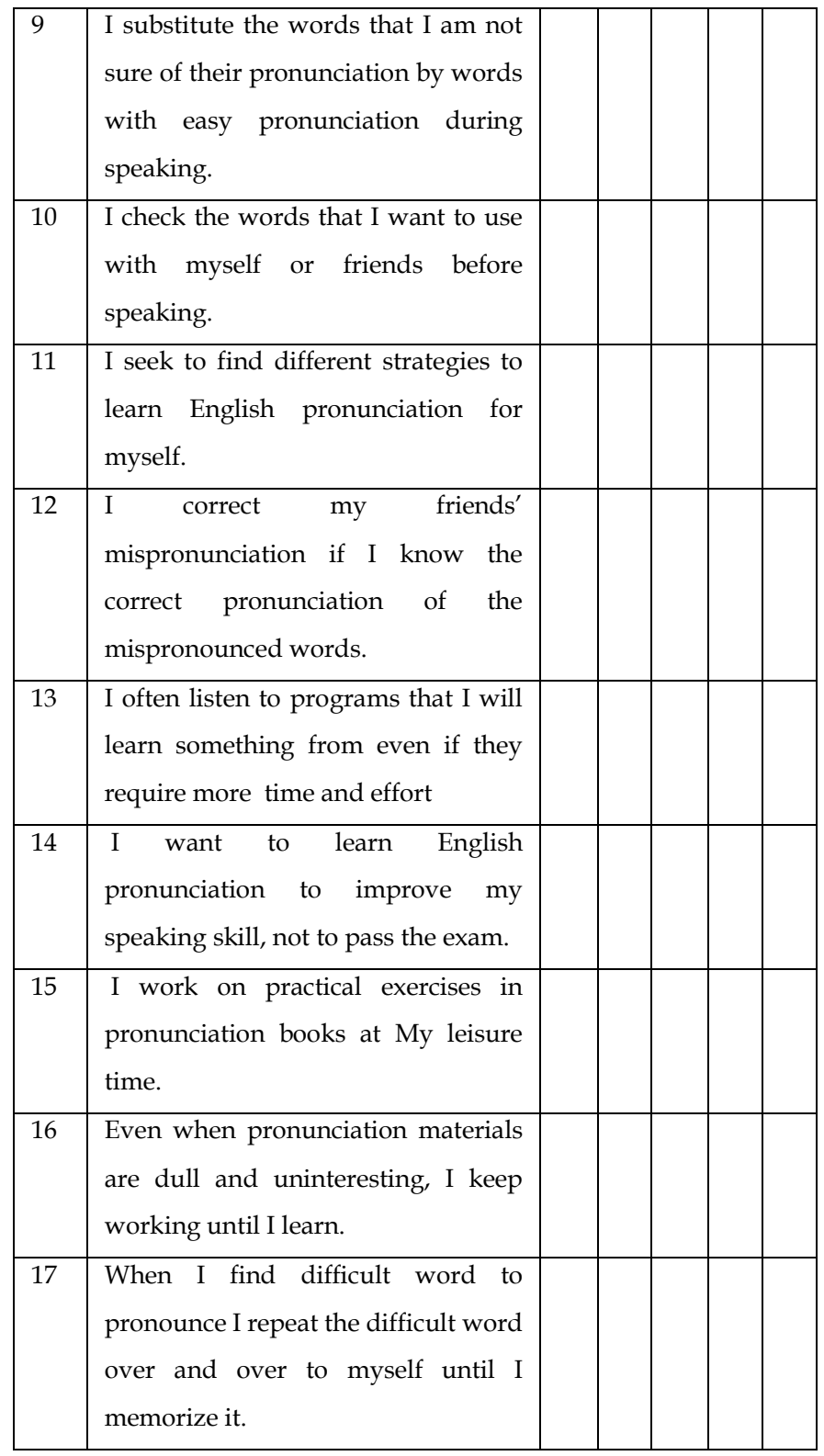

Part three: Do you have your own strategy to monitor yourself during learning the pronunciation of new words? Does it help to develop your selfesteem? 